\title{
Within-person analyses of situational interest and boredom: Interactions between task-specific perceptions and achievement goals
}

Article

Accepted Version

Tanaka, A. and Murayama, K. (2014) Within-person analyses of situational interest and boredom: Interactions between taskspecific perceptions and achievement goals. Journal of Educational Psychology, 106 (4). pp. 1122-1134. ISSN 00220663 doi: https://doi.org/10.1037/a0036659 Available at https://centaur.reading.ac.uk/36406/

It is advisable to refer to the publisher's version if you intend to cite from the work. See Guidance on citing.

To link to this article DOI: http://dx.doi.org/10.1037/a0036659

Publisher: American Psychological Association

All outputs in CentAUR are protected by Intellectual Property Rights law, including copyright law. Copyright and IPR is retained by the creators or other copyright holders. Terms and conditions for use of this material are defined in the End User Agreement. 


\section{CentAUR}

Central Archive at the University of Reading

Reading's research outputs online 
Within-Person Analyses of Situational Interest and Boredom: Interactions Between Task-Specific Perceptions and Achievement Goals

\author{
Ayumi Tanaka \\ Doshisha University, Kyoto, Japan \\ Kou Murayama \\ University of Reading, UK \\ Accepted by Journal of Educational Psychology
}

Author Note

Ayumi Tanaka, Faculty of Psychology, Doshisha University, Kyoto, Japan; Kou Murayama, Department of Psychology, University of Reading, Reading, UK.

This research presented at the annual meeting of the American Educational Research Association, New Orleans, LA, April 2011, and supported in part by Grant-in-Aid for Young Scientists (B) 22730523 from the Japan Society for the Promotion of Science to A. Tanaka.

We thank Suzanne Hidi for her insightful comments on drafts of this article.

Correspondence concerning this article should be addressed to Ayumi Tanaka, Faculty of Psychology, Doshisha University, 1-3 Miyakodani Tatara Kyotanabe, Kyoto 610-0394 Japan. Email: aytanaka@mail.doshisha.ac.jp. 


\begin{abstract}
Despite the increasing number of studies examining the correlates of interest and boredom, surprisingly little research has focused on within-person fluctuations in these emotions, making it difficult to describe their situational nature. To address this gap in the literature, this study conducted repeated measurements (12 times) on a sample of 158 undergraduate students using a variety of self-report assessments, and examined the within-person relationships between task-specific perceptions (expectancy, utility, and difficulty) and interest and boredom. This study further explored the role of achievement goals in predicting between-person differences in these within-person relationships. Utilizing hierarchical-linear modeling, we found that, on average, a higher perception of both expectancy and utility, as well as a lower perception of difficulty, was associated with higher interest and lower boredom levels within individuals. Moreover, mastery-approach goals weakened the negative within-person relationship between difficulty and interest and the negative within-person relationship between utility and boredom. Mastery-avoidance and performance-avoidance goals strengthened the negative relationship between expectancy and boredom. These results suggest how educators can more effectively instruct students with different types of goals, minimizing boredom and maximizing interest and learning.
\end{abstract}

Keywords: interest, expectancy, utility, difficulty, achievement goals 
Within-Person Analyses of Situational Interest and Boredom: Interactions Between Task-Specific Perceptions and Achievement Goals

Interest and boredom are key components of students' academic engagement (Ainley, 2007; Hidi, 2006) and the most frequently experienced emotions in the classroom (Pekrun, Goetz, Daniels, Stupnisky, \& Perry, 2010; Pekrun, Goetz, Titz, \& Perry, 2002; Reeve, Lee, \& Won, in press). Interest is considered a psychological state characterized by a feeling of positive activation or energy directed toward a particular task (Ainley, 2007). While researchers disagree whether interest is an emotion (see Silvia, 2008; Renninger \& Hidi, 2011), the present study sided with those who centered on the affective component and define it as such an emotion (Ainley, 2007; Ainley \& Patrick, 2006; for other possible conceptualizations of interest, see Krapp, 2002; Schiefele, 1991, for example). Interest is associated with increased attention and a willingness to engage in and further investigate the target task (Hidi, 2006). Experiencing interest facilitates a deeper processing of information, a greater quantity and quality of learning, better task organization, and persistence in engagements (see Hidi \& Renninger, 2006, for a review).

In contrast, boredom is considered an affective state characterized by unpleasant feelings, a lack of stimulation, and low physiological arousal (Pekrun et al., 2010). In academic settings, boredom only recently gained attention from researchers as a construct separate from interest (Acee et al., 2010; Goetz, Nett, Frenzel, Lipnevich, \& Hall, 2012; Pekrun et al., 2010). As discussed in detail by Pekrun et al. (2010), boredom is conceptually and empirically distinct from a lack of interest: lack of interest is affectively neutral and does not cause emotional pain. Boredom, on the other hand, includes the feeling that time has slowed down; individuals often experience a desire to escape from the situation (Nett, Goetz, \& Hall, 2011). Previous research has shown that experiences of boredom at school tend to result in detrimental outcomes, including withdrawal of effort (Jarvis \& Seifert, 2002), lower academic achievement (Daniels et al., 2009), and early withdrawal from school (Bearden, Spencer, \& Moracco, 1989).

Importantly, researchers have posited that interest and boredom are first triggered by situations, and develop over time into relatively enduring predispositions (Renninger, 2000). However, aside from a few exceptions (e.g., Moneta \& Csikszentmihalyi, 1996; Nett et al., 2011; Turner \& Silvia, 2006), much of the research on the phenomena of situational interest and boredom has focused on variation in these constructs between individuals (e.g., Ainley \& Ainley, 2011; Chen, Darst, \& Pangrazi, 2001; Daschmann, Goet, \& Stupnisky, 2011; Pekrun et al., 2010). For example, Pekrun et al. (2010) found that students who attach less value to a psychology course report higher boredom for the course than those who value the course more highly. This between-person approach does provide important information about the relationship between situational factors and emotions, in terms of the relative ranking of individuals at a specific time point. However, this approach cannot capture dynamic variations within individuals across situations, making it very difficult to directly examine whether particular individuals feel these emotions in response to situational changes (Murayama, Elliot, \& Yamagata, 2011). Indeed, much methodological work has argued that between-person approaches, both conceptually and mathematically, provide little information about situational effects that occur within individuals (i.e., within-person effects)(e.g., Borsboom, Mellenbergh, \& van Heerden, 2003; Molenaar \& Campbell, 2009; 
Nesselroade, Gerstorf, Hardy, \& Ram, 2007).

Despite the importance of research conducted from a within-person perspective, this approach has been underrepresented particularly in emotion research, and more generally in educational and psychological research (Murayama et al., 2011; Pekrun, 2006; Tsai, Kunter, Lüdtke, Trautwein, \& Ryan, 2008). To fill the gap between theory and empirical evidence, the first aim of the present study was to explore the factors facilitating undergraduates' interest and reducing boredom, focusing on within-person variations in their experiences.

The second aim of this study was to test how individual differences in motivation-specifically, achievement goals - moderate within-person relationships regarding interest and boredom. Achievement goals are defined as competence-relevant aims that individuals strive to accomplish in achievement settings (Pekrun, Elliot, \& Maier, 2009). The theory of achievement goals has been one of the most widely examined motivational frameworks in educational psychology over the past three decades. Achievement goals are thought to exert a broad influence on student outcomes (Elliot, 2005), including achievement-related emotions such as interest and boredom (Pekrun, 2006, 2009). However, most of these studies have focused on the direct or indirect link between achievement goals and achievement emotions (e.g., Ainley \& Patrick, 2006; Daniels et al., 2009; Pekrun, Elliot, \& Maier, 2006, Pekrun et al., 2009). To our knowledge, no study has yet investigated how achievement goals can moderate within-person associations of academic emotions and their correlates. In examining personal achievement goals as moderators, the present study can shed light on the under-examined, dynamic nature of motivational, cognitive, and emotional interactions (see also Murayama \& Elliot, 2009, for a similar perspective).

\section{Situational Antecedents of Academic Interest and Boredom: Perceived Expectancy, Utility, and Difficulty}

While various factors are related to interest and boredom, the present study focused on subjective task perception. Task perception refers to a student's personal evaluative cognitions with regard to, for example, an academic course (Op 't Eynde, De Corte, \& Verschaffel, 2006; Schere, Schorr, \& Johnstone, 2001). Students' emotional reactions toward a course are likely to be shaped by this task-specific evaluative process (Schutz, Pekrun, \& Phye, 2007). Critically, task-specific perceptions vary according to time and situation (Op 't Eynde et al., 2006); therefore, they are potential candidates for predictors of situational fluctuations in interest and boredom. Following the Expectancy-Value Theory in achievement motivation (Eccles et al., 1983), the Control-Value Theory of achievement emotions (Pekrun, 2006), and models of self-regulated learning (Pintrich, 2000), the present study investigated three primary task-specific perceptions as subjective situational antecedents of academic interest and boredom: perceptions of expectancy, utility, and difficulty.

Perception of expectancy refers to one's belief about how well one expects to perform a given activity (Wigfield \& Eccles, 2000), and the prospective perception of the impact of current effort on future outcomes. The term control is often used to refer to this expectation (Pekrun, 2006). Perceived utility is considered one component of task value along with attainment value, intrinsic value, and cost. It refers to the instrumental usefulness of a task to attain present and future goals (Eccles et al., 1983). Tasks with utility 
value are relevant to other tasks or aspects of a person's life beyond the immediate situation (Hulleman, Durik, Schweigert, \& Harackiewicz, 2008). Perception of difficulty is the judgment of the difficulty level of the task, such as how hard it will be to understand course material (Pintrich, 2000). Students experience difficulty when the task is complex and conceptually demanding (Efklides, 2006). These perceptions of difficulty are similar to perceptions of expectancy, although the emphasis is on the task rather than the self (Pintrich, 2000).

High expectations of success in a course may be positively related to interest and negatively related to boredom. Students are more likely to approach the material with confidence, believing that they can accomplish what the situation calls for; this awareness of outcomes and incentives for engagement facilitates learning efforts (Brophy, 2004). High utility of course content may also facilitate interest and prevent boredom. Students develop interest in activities when they find meaning and value in those activities (Hidi \& Renniger, 2006). When students cannot detect meaning in the activities, boredom may result (Pekrun et al., 2002). If the class is perceived to be difficult, that perception may decrease interest and increase boredom, due to the negative affect that arises from an excessive cognitive load and a lack of fluency from interruptions in processing (Efklides, 2006) ${ }^{1}$.

There is growing evidence to support these links discussed above at the between-person level. For example, Goetz, Pekrun, Hall, and Haag (2006) reported that both expectancy-related beliefs and perceptions of achievement value are positively correlated with positive emotions such as enjoyment and pride, and negatively correlated with negative emotions such as anger and boredom for grade 7th-10th-grade Latin students (see also Frenzel, Pekrun, \& Goetz, 2007; Goetz, Frenzel, Hall, \& Pekrun, 2008).

Harackiewicz and colleagues found that students develop interest when they perceive utility value in course topics (e.g., Harackiewicz, Rozek, Hullemen, \& Hyde, 2012; Hulleman et al., 2008; Hulleman, Godes, Hendricks, \& Harackiewicz, 2010; Hulleman \& Harackiewicz, 2009). Dettmers and colleagues (2011) found that 9th and 10th grade students' unpleasant homework-related emotions were negatively affected by homework expectancy and value, and positively affected by perceptions of homework difficulty (see also Pekrun, Frenzel, Goetz, \& Perry, 2007; Renniger \& Hidi, 2011; Schraw \& Lehman, 2001; Wigfield \& Eccles, 2002, for a review).

Most studies to date have explored the relationships between task-specific perceptions and emotional experiences at the between-person level, although interpretations suggest that relationships among these variables occur within individuals. The present study sought to determine whether these findings could be replicated using within-person data. In general, we expected greater interest and less boredom in learning situations that students perceive as high in expectancy and utility and low in task difficulty.

\section{Individual Differences in Within-Person Relationships: The Role of Achievement Goals}

Individual achievement goals have a great impact on appraisal processes and emotions in classrooms (e.g., Hulleman et al., 2008; Liem, Lau, \& Nie, 2008; Pekrun et al., 2006). Students with different achievement goals will experience emotions differently. For a number of years, research focused on two types of goals: mastery and performance. The former concerns individuals' attempts to master tasks and increase their competence, and 
the latter concerns maximizing favorable evaluations of their competence and minimizing negative evaluations of competence. Ever since Elliot and colleagues proposed an extension of this dichotomous model through the incorporation of approach and avoidance goals into mastery and performance goals (see Elliot, 1999; Elliot \& McGregor, 2001), an increasing number of researchers have distinguished between four types of achievement goals: mastery-approach goals, the focus on attaining task-based or intrapersonal competence; mastery-avoidance goals, the focus on avoiding task-based or intrapersonal incompetence; performance-approach goals, the focus on attaining normative competence; and performance-avoidance goals, the focus on avoiding normative incompetence (Elliot \& Murayama, 2008; for different conceptualizations of achievement goals, see Kaplan \& Maehr, 2007; Murayama, Elliot, \& Friedman, 2012, for a review). Mastery-approach goals have been consistently associated with more positive emotions, such as interest and enjoyment of learning, and fewer negative emotions, such as boredom (e.g., Harackiewicz, Durik, Barron, Linnenbrink-Garcia, \& Tauer, 2008; Hulleman et al., 2008; Pekrun et al., 2006, 2009). Performance-approach goals have been found to predict positive emotions such as interest, hope, and pride, while performance-avoidance goals predict less positive emotions, such as interest, in addition to negative emotions such as anxiety and hopelessness (Elliot \& McGregor, 1999; Tanaka, Okuno, \& Yamauchi, 2013; Pekrun et al., 2006, 2009). Although some researchers consider achievement goals to be situation-specific constructs (Nicholls, 1984; Maehr, 1984), recent empirical research indicates that achievement goals can be relatively stable over time, especially within a specific class or course context (Fryer \& Elliot, 2007; see also Bong, 2001; Duda \& Nicholls, 1992, for cross-domain stability of achievement goals).

Achievement goals are also related to situational factors such as perceptions of expectancy, utility, and difficulty. Previous studies have indicated a positive link between mastery-approach and performance-approach goals and perceptions of expectancy and value (Bong, 2001; Conley, 2012; Hulleman et al., 2008; Wigfield, Anderman, \& Eccles, 2000), and a negative link between performance-avoidance goals and expectancy (Elliot \& Church, 1997; Liem, et al., 2008). Damon, Butera, Mugny, Quiamzade, and Hulleman (2009) found that performance-approach and performance-avoidance goals were negatively and positively related to perceptions of difficulty, respectively. Nevertheless, despite the abundant evidence connecting achievement goals, achievement emotions, and task-specific perceptions, to our knowledge, no studies have yet examined the possibility that achievement goals may moderate within-person dynamics between task-specific perceptions and achievement emotions.

Several studies have suggested the moderating roles of motivation or goal-related context in the relationship between interest and task-specific perceptions. Abuhamdeh and Csikszentmihalyi (2009) found that an intrinsic motivational orientation moderated the linear relationship between task difficulty and enjoyment, such that individuals high in intrinsic motivational orientation enjoyed more difficult tasks than individuals low in this orientation. Kumar and Jagacinski (2011) reported that students in ego-involving test situations expressed more negative affect and less positive affect when their perceived ability to perform the task declined. Although they did not compare ego-involving instruction with task-involving instruction, they suggested that the experience of decreasing 
levels of perceived ability would have stronger detrimental effects in ego-involving situations than in task-involving situations. Given that previous research (e.g., Ames, 1992; Butler, 1987; Dweck, 1986; Hulleman, Schrager, Bodmann, \& Harackiewicz, 2010) has indicated that intrinsic motivational orientation and ego-involvement are linked to achievement goals (although they are different constructs), these results suggest that achievement goals could function as moderators for the link between interest and task-specific perceptions.

Mastery-approach goals are related with effort-attributions and positive emotions including interest after failure experiences; since the focus is on learning and understanding material, mistakes are seen as learning opportunities (Dweck, 1999, see also Tulis \& Ainley, 2011). Accordingly, we expect that mastery-approach goals would weaken the negative relationship between perception of difficulty and interest. Performance-approach and avoidance goals are related to the focus on the outcome of task engagement (Hulleman et al., 2008) and the susceptibility to ability-related information (Dweck, 1999; Nicholls, 1984). Therefore, we expect performance-approach goals to strengthen the positive link between perceptions of expectancy and interest, and performance-avoidance goals to strengthen the negative link between perceptions of expectancy and boredom. We made no specific predictions regarding mastery-avoidance goals, because empirical evidence for emotional experience in conjunction with such goals is lacking (see Huang, 2011) and inconsistent (Baranik, Stanley, Bynum, \& Lance, 2010).

Summary

The current study investigated within-person relationships between task-specific perceptions and interest and boredom, and whether achievement goals influence these within-person relationships. We assessed task-specific perceptions, interest, and boredom among the participants repeatedly over the course of a semester. Multiple data collection in this regard enabled us to examine the covariance of the variables within each individual, using the time points as the unit of data analysis (see Murayama et al., 2011). Our data-analytic strategy differs from standard longitudinal data analysis (e.g., panel data analysis), which seeks to examine the predictive relationships of the variables between individuals (i.e., using individual participants as the unit of analysis). Since we used time points as the unit of data analysis, the data had a multilevel structure, with the time points nested within individual participants. We used hierarchical linear modeling (Raudenbush \& Bryk, 2002) to account for the multilevel structure of the data.

We predicted that interest would be positively related to task-specific expectancy and utility and negatively related to task difficulty at the within-person level, and expected the opposite for boredom. We further expected that the between-person variability in achievement goals would moderate these within-person relationships. Specifically, we predicted that mastery-approach goals would weaken the negative relationship between perceived task difficulty and interest, that performance-approach goals would strengthen the positive relationship between perception of expectancy and interest, and that performance-avoidance goals would strengthen the negative relationship between perception of expectancy and boredom.

\section{Participants and Procedure}

\section{Methods}


Participants were undergraduates in an elective introductory psychology class at private university in Japan. This university places upper-middle in nation-wide rankings of Japanese universities' academic performance and is located in an urban area of the Kansai region. The class was conducted in a standard lecture format, and the topics covered in each class (see Table 1) were structured according to the chapters of a psychology textbook. Participants were $18-22$ years old $(M=18.77, S D=0.85)$ and with various majors including literature, economics, commerce, law, and engineering. A semester comprised 12 weeks of classes (denoted as week 1-week 12), excluding a guidance lecture, recess, and the final examination.

During week 1, 162 out of 182 students who had agreed to participate in the study completed consent forms indicating their intention to participate. Participants' achievement goals for the class were assessed in the same week. Since the hierarchical linear model makes no allowance for missing data from level-2 variables (i.e., achievement goals; see the Data Analysis section), we excluded four participants who had missing data for achievement goals from the analysis. This resulted in a final sample of 158 participants (100 male, 57 female, 1 unspecified). From weeks 1 through 12, participants responded to questionnaires on task-specific perceptions (expectancy, utility, and difficulty) and interest and boredom immediately after each class. We made sure that there would be no exam or exam feedback in the course of the assessments, because the stability of achievement goals may be disrupted by those conditions (see Fryer \& Elliot, 2007; Senko \& Harackiewicz, 2005).

In the current study, task-specific perception and interest and boredom were assessed as within-person variables, while achievement goals were assessed as between-person variables. As participants had to respond to measures of within-person variables repeatedly (a total of 12 times), we decided to use a relatively small number of items for these variables to reduce the burden on participants and the concomitant likelihood of careless or disengaged responses.

\section{Measures}

Interest and boredom. Two items from the studies by Wigfield and Eccles (2000) and Eccles and Wigfield (1995) were used to assess situation-specific interest ("Today's class was interesting," "I like today's class."). Two items from the Achievement Emotions Questionnaire (Pekrun, et al., 2002) were used to assess situation-specific boredom ("Today's class bores me," "I find today's class fairly dull."). Participants responded to each item on a 5-point Likert-type scale ranging from 1 (not at all true of me) to 5 (very true of me). The averaged scores for the two items in each category were used to calculate interest and boredom indices.

Task-specific perceptions. We adopted the items from the studies by Wigfield and Eccles (2000) and Eccles and Wigfield (1995) to assess perceptions of expectancy ( 2 items: "On the basis of my comprehension of today's class, I feel I will get a high grade," "On the basis of my comprehension of today's class, I expect I will do well in the final exam compared to other students."), utility ( 2 items: "What I learned in today's class was useful," "Compared to what I studied in other course, what I studied in today's class was useful."), and difficulty ( 2 items: "Today's class was hard for me," "Compared to other courses, today's class was hard for me."). Participants responded to each item on a 5-point 
Likert-type scale ranging from 1 (not at all true of me) to 5 (very true of me). We averaged the two item scores for each of the three perception measures to form three task-specific indices.

Achievement goals. We used the Achievement Goals Questionnaire-Revised (Elliot $\&$ Murayama, 2008) to assess four types of achievement goals: mastery-approach (3 items, e.g., "My aim is to completely master the material presented in this course."), mastery-avoidance (3 items, e.g., "My aim is to avoid learning less than I possibly could."), performance-approach ( 3 items, e.g., "My aim is to perform well relative to other students."), and performance-avoidance (3 items, e.g., "My aim is to avoid doing worse than other students."). Participants responded to each item on a 5-point Likert-type scale ranging from 1 (not at all true of me) to 5 (very true of $m e$ ). Scores for each of the items within a given achievement goal type were averaged to create four goal indices.

\section{Data Analysis}

The data had a two-level hierarchical structure, task-specific perceptions and interest and boredom (Level 1) nested within individuals (Level 2), all collected over a 12 -week period. To appropriately model both within- and between-person relationships in such nested data, we used hierarchical linear modeling (Raudenbush \& Bryk, 2002). For all analyses, solutions were generated on the basis of full maximum-likelihood estimation using the HLM 6 (Raudenbush, Bryk, Cheong, \& Congdon, 2004).

\section{Descriptive Statistics and Zero-Order Correlations \\ Results}

Descriptive statistics of interest, boredom, and task-specific perception (for each time point) and their within-person correlations are reported in Tables 1 and 2, respectively. To calculate Cronbach's alpha coefficients and correlations between these within-person variables, we removed between-person variation in the variables following the formula suggested by Kenny and La Voie (1985). Descriptive statistics and between-person correlations for achievement goals are reported in Table 3. As shown in Table 1, despite the relatively small number of items, the scales show high reliability across the surveys, indicating that the brief scale used in the present study is appropriate for our within-person analysis.

Within-Person Relationships of Task-Specific Perception and Interest and Boredom

In order to gauge the within-person variation of interest and boredom over a semester, we started by testing a null model in which no predictors were entered. Intraclass correlation coefficients (ICC; Kreft \& De Leeuw, 1998) were .30 for interest and .34 for boredom, indicating that $30 \%$ of the variance for interest and $34 \%$ of the variance for boredom can be explained by between-person variation. These results suggest a substantial amount of within-person variability in interest and boredom over a semester $(70 \%$ and $66 \%$, respectively). We then modeled the within-person relationship between task-specific perceptions and interest and boredom, allowing the relationship to vary among individuals (the random coefficient regression model). More specifically, this model specified interest or boredom as the dependent variable and expectancy, utility, and difficulty as joint predictors at the within-person level (Level 1) $)^{2}$. Interest and boredom were modeled separately. The intercepts and the slopes of the predictors were allowed to vary across individuals (Level 2). Thus, the Level 1 equation was 
Interest [Boredom $]_{\mathrm{ij}}=\beta_{0 \mathrm{j}}+\beta_{1 \mathrm{j}}(\text { Expectancy })_{\mathrm{ij}}+\beta_{2 \mathrm{j}}\left(\right.$ Utility $_{\mathrm{ij}}+\beta_{3 \mathrm{j}}(\text { Difficulty })_{\mathrm{ij}}+r_{\mathrm{ij}}$

$(1)$

where the outcome variable, interest [boredom $]_{\mathrm{ij}}$ represents the amount of interest [boredom] in week $i$ for participant $j$. All predictors were group-mean centered, so $\beta_{0 \mathrm{j}}$ represents participant $j$ 's predicted interest when the participant has average scores for expectancy, utility, and difficulty (Enders \& Tofighi, 2007). The parameters $\beta_{1 \mathrm{j}}, \beta_{2 \mathrm{j}}$, and $\beta_{3 \mathrm{j}}$ represent the slopes of the linear relationship between interest [boredom] and expectancy, utility, and difficulty, respectively, for participant $j$. The error term $r_{i j}$ is at the within-person level.

The four parameters $\left(\beta_{0 \mathrm{j}}, \beta_{1 \mathrm{j}}, \beta_{2 \mathrm{j}}\right.$, and $\left.\beta_{3 \mathrm{j}}\right)$ were estimated in Level 2 (i.e., between-person) as follows:

$$
\begin{aligned}
& \beta_{0 \mathrm{j}}=\gamma_{00}+u_{0 \mathrm{j}} \\
& \beta_{1 \mathrm{j}}=\gamma_{10}+u_{1 \mathrm{j}} \\
& \beta_{2 \mathrm{j}}=\gamma_{20}+u_{2 \mathrm{j}} \\
& \beta_{3 \mathrm{j}}=\gamma_{30}+u_{3 \mathrm{j}} \\
& \operatorname{Var}\left(\mathrm{u}_{0 \mathrm{j}}\right)=\tau_{00}, \operatorname{Var}\left(\mathrm{u}_{1 \mathrm{j}}\right)=\tau_{11}, \operatorname{Var}\left(\mathrm{u}_{2 \mathrm{j}}\right)=\tau_{22}, \operatorname{Var}\left(\mathrm{u}_{3 \mathrm{j}}\right)=\tau_{33} .
\end{aligned}
$$

where $\beta_{0 \mathrm{j}}$ is expressed as a function of the average across individuals (between-person intercept, $\left.\gamma_{00}\right)$ and the between-person error term $\left(u_{0 \mathrm{j}}\right)$. The within-person slopes of expectancy $\left(\beta_{1 j}\right)$, utility $\left(\beta_{2 j}\right)$, and difficulty $\left(\beta_{3 j}\right)$ are a function of the average relationship across individuals (between-person slopes $\gamma_{10}, \gamma_{20}$, and $\gamma_{30}$ ), and the between-person residual error $\left(u_{1 \mathrm{j}}, u_{2 \mathrm{j}}\right.$, and $\left.u_{3 \mathrm{j}}\right)$ for participant $j$.

Results are reported in Table 4. Inclusion of task-specific perceptions as predictors explained $33.1 \%$ and $23.5 \%$ of the within-person variance in interest and boredom, respectively. Expectancy and utility were significant positive predictors $\left(\gamma_{10}=0.17, p<.001\right.$, and $\left.\gamma_{20}=0.42, p<.001\right)$ of interest, while difficulty was a significant negative predictor $\left(\gamma_{30}\right.$ $=-0.12, p<.001)$ of interest. Consistent with our hypothesis, on average, students considered a class to be interesting when the class provided a subjective sense of high expectancy, high utility, and low difficulty. However, the variance of the difficulty slope was statistically significant $\left(\tau_{33}=0.04, p<.01\right)$, indicating that the relationship between difficulty and interest differed between individuals.

Similarly, expectancy and utility were significant negative predictors $\left(\gamma_{10}=-0.08, p\right.$ $<.05$, and $\gamma_{20}=-0.29, p<.001$ ) of boredom, while difficulty was a significant positive predictor $\left(\gamma_{30}=0.23, p<.001\right)$ of boredom. This implies that on average, students felt bored when their perceptions of expectancy and utility were low, or perception of difficulty was high. More importantly, however, the variance of the slopes of expectancy and utility were statistically significant $\left(\tau_{11}=0.07, p<.001\right.$ and $\left.\tau_{22}=0.05, p<.01\right)$, indicating that the relationships differed across individuals.

\section{Individual Achievement Goals as a Moderator of Within-Person Relationships between Task-Specific Perceptions and Interest and Boredom}

The previous analysis indicated that although task-specific perceptions are related to interest and boredom at the within-person level, there is also between-person variability in 
these relationships. To account for between-person variations in the effects of task-specific perceptions, we included person-level predictors (i.e., achievement goals) in the model (the slopes-as-outcomes model). Specifically, the parameters $\beta_{0 \mathrm{j}}, \beta_{1 \mathrm{j}}, \beta_{2 \mathrm{j}}$, and $\beta_{3 \mathrm{j}}$ were modeled as a function of the four achievement goal scores. Achievement goal scores were centered on their overall means between individuals to facilitate the interpretation of the intercept term (i.e., "grand-mean centering"). The equations representing the full version of the model were as follows:

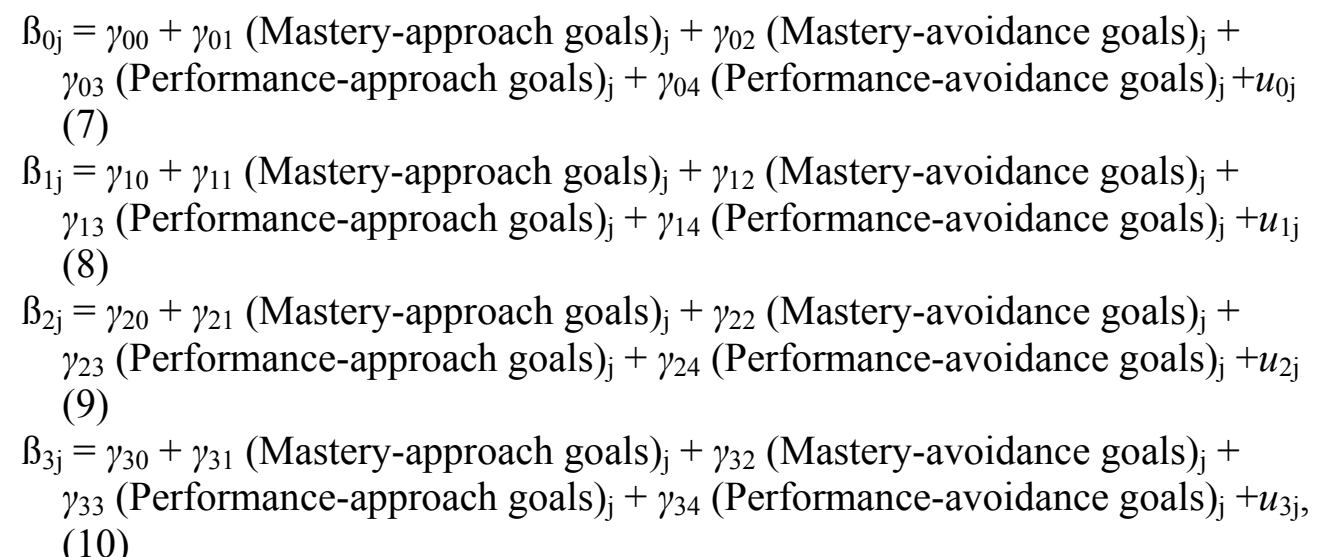

where $\gamma_{10}, \gamma_{20}$, and $\gamma_{30}$ are average slopes of the expectancy, utility, and difficulty for interest [boredom] across individuals, respectively. Further, $\gamma_{01}-\gamma_{04}$ represent the effects of mastery-approach, mastery-avoidance, performance-approach, and performance-avoidance goals on interest across individuals ${ }^{3}$. The coefficients of central interest in the present analysis are the effects of achievement goals on the relationships between each of task-specific perceptions and interest [boredom] $\left(\gamma_{11}-\gamma_{14}, \gamma_{21}-\gamma_{24}\right.$, and $\left.\gamma_{31}-\gamma_{34}\right)$. For example, $\gamma_{11}$, represents the effect of mastery-approach goals on the relationship between expectancy and interest [boredom] across individuals.

As this model has many parameters and may result in unstable parameter estimates (see Raudenbush \& Bryk, 2002), we decided to include achievement goals for only the intercepts and slopes with significant between-person variance; non-significant predictors were also omitted from the model. The results are reported in Table 5.

The first section of Table 5 shows that mastery-approach and mastery-avoidance goals were significant positive predictors of the interest intercept $\left(\gamma_{01}=0.22, p<.01\right.$, and $\left.\gamma_{02}=0.14, p<.05\right)$. This indicates that the more the participants adopted these goals, the more they reported interest in the class over the course of the semester. Mastery-approach goals were also significant negative predictors of the boredom intercept $\left(\gamma_{01}=-0.24, p\right.$ $<.001)$. This indicates that the more the participants adopted mastery-approach goals, the less they reported boredom. We found no significant influence of performance-approach or performance-avoidance goals on the intercepts of either interest or boredom. Achievement goals explained $20.3 \%$ of between-person variance in the intercept for interest and $10.9 \%$ of variance in the intercept for boredom.

More importantly, with regard to the slopes of interest, mastery-approach goals were 
a significant positive predictor of the difficulty slope $\left(\gamma_{31}=0.13, p<.01\right)$. To facilitate interpretation, we plotted the association between difficulty and interest, comparing high and low mastery-approach goals (Figure 1). We conducted simple slope analyses that tested the significance of the difficulty slopes at mastery-approach goal values one standard deviation above and below the sample mean (Bauer \& Curran, 2005). The results revealed that although difficulty was a significant negative predictor of interest on average (i.e., $\gamma_{30}=$ $-0.12, p<.001)$, the association was only present in individuals with low mastery-approach goals (estimated beta $=-0.20, p<.001$ ). For those with high mastery-approach goals, utility was not significantly related to boredom (estimated beta $=-0.04, n . s$.). The between-person variance in difficulty slope was explained $7.0 \%$ by adding mastery-approach goals to the model.

For the slopes of boredom, mastery-avoidance goals and performance-avoidance goals were significant negative predictors of the expectancy slope $\left(\gamma_{12}=-0.12, p<.05\right.$, and $\left.\gamma_{14}=-0.08, p<.05\right)$. Although expectancy was a significant negative predictor of boredom on average (i.e., $\gamma_{10}=-0.09, p<.05$ ), the results of simple slope analysis revealed that associations were evident only for individuals with high mastery-avoidance goals (estimated beta $=-0.17, p<.05$ ) or high performance-avoidance goals (estimated beta $=$ $-0.16, p<.01$; Figure 2). For those with low mastery-avoidance and performance-avoidance goals, there was no significant relationship between expectancy and boredom (estimated beta $=-0.01$ and -0.02 , respectively). The between-person variance in expectancy slope was explained $7.5 \%$ by adding mastery-avoidance and performance-avoidance goals to the model.

Mastery-approach goals were a significant positive predictor of the utility slope ( $\gamma_{21}$ $=0.13, p<.05)$. Utility was, on average, significantly and negatively related with boredom (i.e., $-0.29, p<.001$ ). However, as shown in Figure 3, the association was smaller for individuals with high mastery-approach goals (estimated beta $=-0.21, p<.001$ ) than for those with low mastery-approach goals (estimated beta $=-0.37, p<.001$ ). The between-person variance in utility slope was explained $16.0 \%$ by adding mastery-approach goals to the model.

\section{Discussion}

Student engagement is vital to effective learning and academic development. Interest and boredom are central indicators of classroom emotional engagement and emotional disaffection (Skinner, Furrer, Marchand, \& Kindermann, 2008). The present study attempted to contribute to the literature on academic interest and boredom in undergraduate students by analyzing the dynamic links among cognitive appraisals, emotions, and motivational orientations. The results generally supported our predictions regarding within-person relationships among task-specific perceptions and interest and boredom, and the moderation of within-person relationships by achievement goals.

\section{Within-Person Antecedents of Academic Interest and Boredom}

In line with the Expectancy-Value Theory (Eccles et al., 1983) and the

Control-Value Theory (Pekrun, 2006), the results from our within-person analysis showed that interest was positively related with the perception of expectancy and utility and negatively related with the perception of difficulty. Conversely, boredom was negatively related with expectancy and utility and positively related with difficulty. These findings 
confirmed our hypothesis that expectancy, utility, and difficulty are situational appraisals that uniquely and powerfully contribute to academic engagement (Pintrich, 2000; Pekrun et al., 2007). Crucially, our results attest to these relationships at the within-person level. These results indicate that previous findings on situational influences on interest and boredom at the between-person level (e.g., Dettmers et al., 2011; Goetz et al., 2006; Pekrun et al., 2010) could be generalized to the within-person level, providing empirical evidence for the situational nature of interest and boredom in classrooms (Renninger, 2000).

\section{The Moderating Influence of Achievement Goals}

The current study also showed that individual differences in achievement goals moderated the within-person relationships between task-specific perceptions and interest and boredom in several ways. As expected, difficulty negatively predicted interest for students with low mastery-approach goals; this relationship was absent in those with high mastery-approach goals. Although a university's academic setting is complex and challenging (Pekrun et al., 2010), our findings indicate that students with high mastery-approach goals maintain interest even when they have perceived difficulty understanding course materials. Mastery-oriented students strive to increase their skills and knowledge, embracing academic challenges (Dweck, 1999). These characteristics may enable students to persist in the face of cognitive costs and a lack of fluency stemming from the interruption of processing, which usually elicits negative emotions (Efklides, 2006). Our findings clearly indicate the importance of facilitating mastery-approach goals in classrooms in order to sustain students' academic interest when they encounter difficult learning materials.

We did not anticipate that mastery-approach goals would moderate the relationship between perceived utility and boredom. Specifically, the negative relationship between utility and boredom was weakened for those with high mastery-approach goals compared to students with low mastery-approach goals. These results suggest that the lack of perceived utility regarding learning materials can be a source of boredom, particularly when students are not mastery oriented. Perceived utility of a task is an incentive for engaging in it (Eccles, 2005; Eccles \& Wigfield, 1995) and contributes individuals to continue to engage in the activity (Hidi \& Renninger, 2006). Students with high mastery-approach goals focus on the process rather than outcome or product of task engagement (Hullemen et al., 2008); thus, they do not necessarily feel bored, even when the immediate benefits of learning are unclear.

Note, however, that our measure of perceived utility (e.g., "What I learned in today's class was useful") leaves some ambiguity in the conceptualization of task utility, in that the measure did not specify the target of utility (i.e., useful for what?). Accordingly, our measure may have encompassed qualitatively different aspects of task utility. For example, a task can be useful when the task is goal-relevant (e.g., "this knowledge is useful for my future career"), but it is also possible that a goal-irrelevant task is viewed as useful (e.g., "this knowledge is useful for life in general"). Furthermore, some researchers suggested that, depending on the target of the utility, utility value could be either intrinsic or extrinsic (see Goetz et al., 2006; Simons, Dewitte, \& Lens, 2004; Vansteenkiste et al., 2004). For example, in the context of Latin language instruction, Goetz et al. (2006) distinguished two types of Latin utility value: the value of Latin as a subject and the value of achievement in 
Latin. These distinct values were referred as intrinsic and extrinsic values, although they found a similar correlational pattern with enjoyment and boredom in Latin for both of these values. The precise role of perceived utility in facilitating interest and alleviating boredom as a function of achievement goals should wait for future studies that distinguish these different types of utility values.

We hypothesized that perception of expectancy would be related to interest in students with high performance-approach goals, as students with these goals are susceptible to ability-related information (Dweck, 1999; Nicholls, 1984). However, contrary to our prediction, performance-approach goals did not moderate the positive relationship between expectancy and interest. As students with performance-approach goals can declare success only when they surpass other students, they may need external information regarding their relative standing in the classroom in order to judge their performance (Senko \& Harackiewicz, 2005; see also Dweck \& Elliott, 1983). The engagement of students with performance-approach goals may, therefore, be influenced by perceptions regarding whether and to what extent they are currently outperforming others, rather than the uncertain expectation that they will do well in the future, as was assessed in the present study.

Although we did not find significant moderating effects for performance-approach goals in interest and boredom, it should be noted that these goals may still play a moderating role in the within-person dynamics of other types of achievement emotions. For example, in examining the pattern of bivariate correlations between achievement goals and specific emotions, Pekrun et al. (2006, 2009) found that performance-approach goals were related to hope and pride, but not to interest. Linnenbrink and Pintrich (2002) suggested that students with performance-approach goals should experience pride when they are progressing toward their goal of outperforming others, and anxiety and sadness when they feel that they are not making sufficient progress or that they do not have the ability to meet a desired goal. While little is known about achievement goals' moderating influence on emotional experiences in general, further research should identify how performance-approach goals relate to emotional engagement in the classroom.

With regard to performance-avoidance goals, we obtained a pattern of results consistent with our prediction: a lower perception of expectancy led to increased boredom for students who were high in performance-avoidance goals as compared to students who were low in performance-avoidance goals. Unexpectedly, as shown in Figure 2, a similar moderating effect was found for mastery-avoidance goals. These results may indicate the sensitivity and vulnerability of avoidance goals to ability-related information, unspecific to performance-avoidance goals. Researchers have yet to understand the function of avoidance-valence goals, because few studies have systematically compared the functions of the four types of achievement goals in the classroom (see Cury, Elliot, Da fonesca, \& Moller, 2006; Elliot \& Murayama, 2008; Pastor, Barron, Miller, \& Davis, 2007; Sideridis, 2007; Van Yperen, 2006, for exceptions). Further research is needed to examine the differential roles of performance-avoidance and mastery-avoidance goals, especially in the context of within-person analysis.

\section{Implications for Educational Practices}

What can educators do to foster students' interest and reduce boredom in the 
classroom? The primary recommendations based on the present findings are straightforward: raise students' perception of expectancy, emphasize the utility of the course content, and ensure that tasks are not too difficult. For this purpose, the instructor should "teach things that are worth learning, in ways that help students to appreciate their value" (Brophy, 2004, p. 33), and "support students" confidence as learners" (p. 66). Instructors should do two things: bring the lesson to the students, and bring the students to the lesson (Blumenfeld, Puro, \& Mergendoller, 1992). The former refers to opportunities instructors should provide for students to learn, including helping them to see the value in what they are learning. The latter concerns students' active thinking about the lesson, with the instructors' support.

Our findings also indicate a more nuanced reality, in which patterns of results differ as a function of individual differences in students' motivational patterns. Accordingly, educators should pay more attention to students' achievement motivations (e.g., achievement goals) as well as to task contents and structure (e.g., difficulty and utility) to more fully understand students' emotional engagement and academic experience. Difficult learning materials may discourage students and decrease students' intrinsic interest, but our findings also showed that this is not necessarily the case when students are mastery-approach oriented. In classrooms where the majority of students have mastery-approach goals, teachers need not avoid difficult materials out of worry over losing students' interest. Similarly, although lower self-confidence tends to increase boredom, our results indicated that this negative link can be mitigated by decreasing students' mastery-avoidance and performance-avoidance goals. Accordingly, when teachers find that a number of their students have mastery-avoidance or performance-avoidance goals, they should take care to support and bolster students' self-confidence to avoid classroom boredom.

\section{Limitations and Future Directions}

This study is characterized by several strengths, including repeated data collection, study in a naturalistic setting, and high assessment reliability with parsimonious measures. Despite these strengths, the results must be interpreted in light of several limitations. First, this study was conducted in a context of an introductory psychology course at one Japanese university; therefore, the generalizability of the results to other academic settings is limited and should be tested in future empirical research. Second, we relied on survey methodology in field settings and self-reported measures. Alternative methods such as behavioral observation or physiological measurement of interest and boredom should be utilized for a comprehensive understanding of academic engagement (Renniger \& Hidi, 2011). In addition, we did not examine the influence of lecture contents and materials in terms of students' experiences of expectancy, utility, and difficulty. Given that these are objective features and structures that teachers can directly manipulate in the classroom, future research should incorporate such objective environmental aspects.

Situational interest and boredom have formed part of the theoretical underpinning of the literature on motivation and achievement emotions (Krapp, 2002; Hidi \& Renninger, 2006), but there has been a surprising lack of empirical research on the transient, situation-specific nature of these emotions. The present study is one of the first attempts to fill the gap between the theoretical perspective and empirical inquiries. Although we must 
continue to examine the within-person, situational correlates of these emotions, another important next step would be to investigate how educators can support students in developing and transferring these situational interests to others that both endure over time and deepen across topics and subject areas (i.e., personal interests). Previous studies have suggested that repeated experiences of situational interest (Guthrie et al., 2006), mastery-goal classroom structure (Ames, 1992), and instruction that is supportive of autonomy (Reeve, 2002) are key factors in this process, but empirical evidence directly connecting situational and personal interests is still underway. Thus additional research is still needed to take the next step in investigating the important developmental processes of interest and boredom. 


\section{References}

Acee, T. W., Kim, H., Kim, H. J., Kim, J., Chu, H., Kim, M. ... Boredom Research Group. (2010). Academic boredom in under- and over-challenging situations. Contemporary Educational Psychology, 35, 17-27. doi: 10.1016/j.cedpsych.2009.08.002

Abuhamdeh, S., \& Csikszentmihalyi, M. (2009). Intrinsic and extrinsic motivational orientations in the competitive context: An examination of person-situation interactions. Journal of Personality, 77, 1615-1635. doi: $10.1111 / \mathrm{j} .1467-6494.2009 .00594 . x$

Ainley, M. (2007). Being and feeling interested: Transient state, mood, and disposition. In P. A. Schutz \& R. Pekrun (Eds.). Emotion in education (pp. 57-73). San Diego, CA: Academic Press.

Ainley, M., \& Ainley, J. (2011). Student engagement with science in early adolescence: The contribution of enjoyment to students' continuing interest in learning about science. Contemporary Educational Psychology, 36, 4-12. doi: 10.1016/j.cedpsych.2010.08.001

Ainley, M., \& Patrick, L. (2006). Measuring self-regulated learning processes through tracking patterns of student interaction with achievement activities. Educational Psychology Review, 18, 267-286. doi: 10.1107/s10648-006-9018-z

Ames, C. (1992). Classrooms: Goals, structures, and student motivation. Journal of Educational Psychology, 84, 261-271. doi: 10.1037//0022-0663.84.3.261

Atkinson, J. W. (1957). Motivational determinants of risk-taking behavior. Psychological Review, 64, 359-372. doi: 10.1037/h0043445

Baranik, L. E., Stanley, L. J., Bynum, B. H., \& Lance, C. E. (2010). Examining the construct validity of mastery-avoidance achievement goals: A meta-analysis. Human Performance, 23, 265-282. doi: 10.1080/08959285.1010.488463

Bauer, D. J., \& Curran, P. J. (2005). Probing interactions in fixed and multilevel regression: Inferential and graphical techniques. Multivariate Behavioral Research, 40, 373-400. doi: 10.1207/s15327906mbr4003 5

Bearden, L. J., Spencer, W. A., \& Moracco, J. C. (1989). A study of high school dropouts. School Counselor, 37, 113-120.

Bong, M. (2001). Between- and within-domain relations of academic motivation among middle and high school students: Self-efficacy, task-value, and achievement goals. Journal of Educational Psychology, 93, 23-34. doi: 10.1037//0022-0663.93.1.23

Borsboom, D., Mellenbergh, G. J., \& van Heerden, J. (2003). The theoretical status of latent variables. Psychological Review, 110, 203-219. doi: 10.1037/0033-295X.110.2.203

Brophy, J. E. (2004). Motivating students to learn (2nd ed.). Mahwah, NJ: Erlbaum.

Blumenfeld, P., Puro, P., \& Mergendoller, J. (1992). Translating motivation into thoughtfulness. In H. Marchall (Ed.), Redefining student learning: Roots of educational change (pp. 207-239). Norwood, NJ: Ablex.

Butler, R. (1987). Task-involving and ego-involving properties of evaluation: Effects of different feedback conditions on motivational perceptions, interest and 
performance. Journal of Educational Psychology, 79, 474-482. doi: $10.1037 / / 0022-0663.79 .4 .474$

Chen, A., Darst, P. W., \& Pangrazi, R. P. (2001). An examination of situational interest and its sources. British Journal of Educational Psychology, 71, 383-400. doi: 10.1348/000709901158578

Cohen, J., Cohen, P., West, S. G., \& Aiken, L. S. (2003). Applied Multiple Regression/Correlation Analysis for the Behavioral Sciences (3rd ed.). Mahwah, NJ: Lawrence Erlbaum Associates Publishers.

Conley, A. M. (2012). Patterns of motivation beliefs: Combining achievement goal and expectancy-value perspectives. Journal of Educational Psychology, 104, 32-47. doi: 10.1037/a0026042

Csikszentmihalyi, M. (1990). Flow: The psychology of optimal experience. New York: Harper \& Row.

Cury, F., Elliot, A. J., Da fonesca, D., \& Moller, A. C. (2006). The social-cognitive model of achievement motivation and the $2 \times 2$ achievement goal framework. Journal of Personality and Social Psychology, 90, 666-679. doi: 10.1037/0022-3514.90.4.666

Daniels, L. M., Stupnisky, R. H., Pekrun, R., Haynes, T. L., Perry, R. P., \& Newall, N. E. (2009). A longitudinal analysis of achievement goals: From affective antecedents to emotional effects and achievement outcomes. Journal of Educational Psychology, 101, 948-963. doi: 10.1037/a0016096

Darnon, C., Butera, F., Mugny, G., Quiamzade, A., \& Hulleman, C. S. (2009). "Too complex for me!" Why do performance-approach and performance-avoidance goals predict exam performance? European Journal of Psychology of Education, 24, 423-434. doi: 10.1007/BF03178759

Daschmann, E. C., Goetz, T., Stupnisky, R. H. (2011). Testing the predictors of boredom at school: Development and validation of the precursors to boredom scales. British Journal of Educational Psychology, 81, 421-440. doi: 10.1348/000709910X526038

Dettmers, S., Trautwein, U., Lüdtke, O., Goetz, T., Frenzel, A. C., \& Pekrun, R. (2011). Students' emotions during homework in mathematics: Testing a theoretical model of antecedents and achievement outcomes. Contemporary Educational Psychology, 36, 25-35. doi: 10.1016/j.cedpsych.2010.10.001

Duda, J. L., \& Nicholls, J. G. (1992). Dimensions of achievement motivation in schoolwork and sport. Journal of Educational Psychology, 84, 290-299. doi: $10.1037 / / 0022-0663.84 .3 .290$

Dweck, C. S. (1986). Motivational processes affecting learning. American Psychologist, 41, 1040-1048. doi: 10.1037//0003-066X.41.10.1040

Dweck, C. S. (1999). Self-theories: Their role in motivation, personality, and development. Philadelphia: Taylor \& Francis.

Dweck, C. S., \& Elliott, E. S. (1983). Achievement motivation. In P. H. Mussen (Gen. ed.) \& E. M. Hetherington (Vol. ed.), Handbook of child psychology: Vol. 4. Social and personality development (pp. 643-691). New York: Wiley.

Eccles, J. S. (2005). Subjective task value and the Eccles et al. model of 
achievement-related choices. In A. J. Elliot \& C. S. Dweck (Eds.), Handbook of competence and motivation (pp. 105-121). New York: Guilford Press.

Eccles, J. S., Adler, T. F., Futterman, R., Goff, S. B., Kaczala, C. M., Meece, J. L., \& Midgley, C. (1983). Expectancies, values, and academic behaviors. In J. T. Spence (Ed.), Achievement and achievement motivation (pp. 75-146). San Francisco, CA: W. H. Freeman.

Eccles, J. S. \& Wigfield, A. (1995). In the mind of the achiever: The structure of adolescents' achievement task values and expectancy-related beliefs. Personality and Social Psychology Bulletin, 21, 215-225.

Efklides, A. (2006). Metacognition and affect: What can metacognitive experiences tell us about the learning process? Educational Research Review, 1, 3-14. doi: 10.1016/j.edurev.2005.11.001

Elliot, A. J. (1999). Approach and avoidance motivation and achievement goals. Educational Psychologist, 34, 169-189. doi: 10.1207/s15326985ep3403_3

Elliot, A. J. (2005). A conceptual history of the achievement goal construct. In A. J. Elliot \& C. S. Dweck (Eds.), Handbook of competence and motivation (pp. 52-72). New York, NY: Guilford.

Elliot, A. J., \& Church, M. (1997). A hierarchical model of approach and avoidance achievement motivation. Journal of Personality and Social Psychology, 72, 218-232. doi: 10.1037//0022-3514.72.1.218

Elliot, A. J., \& McGregor, H. (1999). Test anxiety and the hierarchical model of approach and avoidance achievement motivation. Journal of Personality and Social Psychology, 76, 461-475. doi: 10.1037//0022-3514.76.4.628

Elliot, A. J., \& McGregor, H. (2001). A $2 \times 2$ achievement goal framework. Journal of Personality and Social Psychology, 80, 501-519. doi: 10.1037//0022-3514.80.3.501

Elliot, A. J., \& Murayama, K. (2008). On the measurement of achievement goals: Critique, illustration, and application. Journal of Educational Psychology, 100, 613-628. doi: $10.1037 / 0022-0663.100 .3 .613$

Enders, C. K., \& Tofighi, D. (2007). Centering predictor variables in cross-sectional multilevel models: A new look at an old issue. Psychological Methods, 12, 121-138. doi: 10.1037/1082-989X.12.2.121

Frenzel, A., Pekrun, R., \& Goetz, T. (2007). Perceived learning environment and students' emotional experiences: A multilevel analysis of mathematics classrooms. Learning and Instruction, 17, 478-493. doi: 10.1016/j.learninstruc.2007.09.001

Fryer, J. W., \& Elliot, A. J. (2007). Stability and change in achievement goals. Journal of Educational Psychology, 99, 700-714. doi: 10.1037/0022-0663.99.4.700

Goetz, T., Frenzel, A., Hall, N., \& Pekrun, R. (2008). Antecedents of academic emotions: Testing the internal/external frame of reference model for academic enjoyment. Contemporary Educational Psychology, 33, 9-33.

doi: 10.1016/j.cedpsych.2006.12.002

Goetz, T., Nett, U. E., Frenzel, A. C., Lipnevich A. A., \& Hall, N. C. (2012, April). Types of 
students'Boredom: An experience sampling approach. Paper presented at the Annual Meeting of the American Educational Research Association, Vancouver, Canada.

Goetz, T., Pekrun, R., Hall, N., \& Haag, L. (2006). Academic emotions from a social-cognitive perspective: Antecedents and domain specificity of students' affect in the context of Latin instruction. British Journal of Educational Psychology, 76, 289-308. doi: 10.1348/000709905X42860

Guthrie, J. T., Wigfield, A., Humenick, H. M., Perencevich, K. C., Taboada, A., \& Barbosa, P. (2006). Influences of stimulating tasks on reading motivation and comprehension. Journal of Educational Research, 99, 232-245. doi: 10.3200/JOER.99.4.232-246

Harackiewicz, J. M., Durik, A. M., Barron, K. E., Linnenbrink-Garcia, L., \& Tauer, J. M. (2008). The role of achievement goals in the development of interest: Reciprocal relations between achievement goals, interest, and performance. Journal of Educational Psychology, 100, 105-122. doi: 10.1037/0022-0663.100.1.105

Harackiewicz, J. M., Rozek, C. S., Hulleman, C. S., \& Hyde, J. S. (2012). Helping parents to motivate adolescents in mathematics and science: An experimental test of a utility-value intervention. Psychological Science, 23, 899-906. doi: $10.1177 / 0956797611435530$

Hidi, S. (2006). Interest: A unique motivational variable. Educational Research Review, 1, 69-82. doi: 10.1016/j.edurev.2006.09.001

Hidi, S., \& Renniger, A. (2006). The four-phase model of interest development. Educational Psychologist, 41, 111-127. doi: 10.1207/s15326985ep4102_4

Huang, C. (2011). Achievement goals and achievement emotions: A meta-analysis. Educational Psychology Review, 23, 359-388. doi: 10.1007/s10648-011-9155-x

Hulleman, C., Durik, A. M., Schweigert, S., \& Harackiewicz, J. M. (2008). Task values, achievement goals, and interest: An integrative analysis. Journal of Educational Psychology, 100, 398-416. doi: 10.1037/0022-0663.100.2.398

Hulleman, C., Godes, O., Hendricks, B. L., \& Harackiewicz, J. M. (2010). Enhancing interest and performance with a utility value intervention. Journal of Educational Psychology, 102, 880-895. doi: 10.1037/a0019506

Hulleman, C., \& Harackiewicz, J. M. (2009). Promoting interest and performance in high school science classes. Science, 326, 1410-1412. doi: 10.1126/science.1177067

Hulleman, C. S., Schrager, S. M., Bodmann, S. M., \& Harackiewicz, J. M. (2010). A meta-analytic review of achievement goal measures: Different labels for the same constructs or different constructs with similar labels? Psychological Bulletin, 136, 422-449. doi: 10.1037/a0018947

Jarvis, S., \& Seifert, T. (2002). Work avoidance as a manifestation of hostility, helplessness, and boredom. Alberta Journal of Educational Research, 48, 174-187.

Kaplan, A., \& Maehr, M. L. (2007). The contributions and prospects of goal orientation theory. Educational Psychology Review, 19, 141-184. doi: $10.1007 / \mathrm{s} 10648-006-9012-5$

Kenny, D. A., \& La Voie, L. (1985). Separating individual and group effects. Journal of Personality and Social Psychology, 48, 339-348. 
doi: $10.1037 / / 0022-3514.48 .2 .339$

Krapp, A. (2002). Structural and dynamic aspects of interest development: Theoretical considerations from an ontogenetic perspective. Learning and Instruction, 12, 383-409. doi: 10.1016/S0959-4752(01)00011-1

Kreft, I., \& De Leeuw, J. (1998). Introducing multilevel modeling. London: Sage.

Kumar, S., \& Jagacinski, C. M. (2011). Confronting task difficulty in ego involvement:

Change in performance goals. Journal of Educational Psychology, 103, 664-682. doi: $10.1037 / \mathrm{a} 0023336$

Liem, A. D., Lau, S., \& Nie, Y. (2008). The role of self-efficacy, task value, and achievement goals in predicting cognitive engagement, task disengagement, peer relationship, and achievement outcome. Contemporary Educational Psychology, 33, 486-512. doi: 10.1016/j.cedpsych.2007.08.001

Linnenbrink, E. A., \& Pintrich, P. R. (2002). Achievement goal theory and affect: An asymmetrical bidirectional model. Educational Psychologist, 37, 69-78. doi: $10.1207 / \mathrm{S} 15326985 \mathrm{EP} 37022$

Maehr, M. L. (1984). Meaning and motivation: Toward a theory of personal investment. In R. E. Ames \& C. Ames (Eds.), Research on motivation in education (Vol. 1, pp. 115-144). New York, NY: Academic Press.

Moneta, G. B., \& Csikszentmihalyi, M. (1996). The effect of perceived challenges and skills on the quality of subjective experience. Journal of Personality, 64, 275-310. doi: 10.1111/j.1467-6494.1996.tb00512.x

Molenaar, P. C. M., \& Campbell, C. G. (2009). The new person-specific paradigm in psychology. Current Directions in Psychological Science, 18, 112-117. doi: 10.1111/j.1467-8721.2009.01619.x

Murayama, K., \& Elliot, A. J. (2009). The joint influence of personal achievement goals and classroom goal structures on achievement-relevant outcomes. Journal of Educational Psychology, 101, 432-447. doi: 10.1037/a0014221

Murayama, K., Elliot, A. J., \& Friedman, R. (2012). Achievement goals and approach-avoidance motivation. In R. M. Ryan (ed.), The Oxford handbook of human motivation (pp. 191-207). Oxford: Oxford University Press.

Murayama, K., Elliot, A. J., \& Yamagata, S. (2011). Separation of performance-approach and performance-avoidance goals: A broader analysis. Journal of Educational Psychology, 103, 238-256. doi: 10.1037/a0021948

Nesselroade, J. R., Gerstorf, D., Hardy, S. A., \& Ram, N. (2007). Idiographic filters for psychological constructs. Measurement: Interdisciplinary Research and Perspectives, 5, 217-235. doi: 10.1080/15366360701741807

Nett, U. E., Goetz, T., \& Hall, N. C. (2011). Coping with boredom in school: An experience sampling perspective. Contemporary Educational Psychology, 36, 49-56. doi: 10.1016/j.cedpsych.2010.10.003

Nicholls, J. G. (1984). Achievement motivation: Conceptions of ability, subjective experience, task choice, and performance. Psychological Review, 91, 328-346. doi: 10.1037//0033-295X.91.3.328

Op 't Eynde, P., De Corte, E., \& Verschaffel, L. (2006). Students' emotions: A key component of self-regulated learning? In P. A. Schutz \& R. Pekrun (Eds.). 
Emotion in education (pp. 57-73). San Diego, CA: Academic Press.

Pastor, D. E., Barron, K. E., Miller, B. J., \& Davis, S. L. (2007). A latent profile analysis of college students' achievement goal orientation. Contemporary Educational Psychology, 32, 8-47. doi: 10.1016/j.cedpsych.2006.10.003

Pekrun, R. (2006). The control-value theory of achievement emotions: Assumptions, corollaries, and implications for educational research and practice. Educational Psychology Review, 18, 315-341. doi: 10.1007/s10648-006-9029-9

Pekrun, R. (2009). Emotions at school. In K. Wentzel \& A. Wigfield (Eds.). Handbook of motivation at school (pp. 575-604). London: Routledge.

Pekrun, R., Elliot, A. J., \& Maier, M. A. (2006). Achievement goals and discrete achievement emotions: A theoretical model and prospective test. Journal of Educational Psychology, 98, 583-597. doi: 10.1037/0022-0663.98.3.583

Pekrun, R., Elliot, A. J., \& Maier, M. A. (2009). Achievement goals and achievement emotions: Testing a model of their joint relations with academic performance. Journal of Educational Psychology, 101, 115-135. doi: 10.1037/a0013383

Pekrun, R., Frenzel, A., Goetz, T., \& Perry, R. P. (2007). The control-value theory of achievement emotions: An integrative approach to emotions in education. In P. A. Schutz \& R. Pekrun (Eds.), Emotion in education (pp. 13-36). San Diego, CA: Academic Press.

Pekrun, R., Goetz, T., Daniels, L. M., Stupnisky, R. H., \& Perry, R. P. (2010). Boredom in achievement settings: Exploring control-value antecedents and performance outcomes of a neglected emotion. Journal of Educational Psychology, 102, 531-549. doi: 10.1037/a0019243

Pekrun, R., Goetz, T., \& Titz, W., \& Perry, R. P. (2002). Academic emotions in students' self-regulated learning and achievement: A program of qualitative and quantitative research. Educational Psychologist, 37, 91-105. doi: 10.1207/S15326985EP3702_4

Pintrich, P. R. (2000). The role of goal orientation in self-regulated learning. In M. Boekaerts, P. Pintrich \& M. Zeidner (Eds.), Handbook of self-regulation (pp. 451-502). San Diego: Academic Press.

Raudenbush, S. W., \& Bryk, A. S. (2002). Hierarchical linear models: Applications and data analysis methods (2nd ed.). Newbury Park, CA. Sage.

Raudenbush, S. W., \& Bryk, A. S., Cheong, Y. F., \& Congdon, R. T. (2004). HLM 6: Hierarchical linear and nonlinear modeling. Lincolnwood, IL: Scientific Software International.

Reeve, J. (2002). Self-determination theory applied to educational settings. In E. L. Deci \& R. M. Ryan (Eds.), Handbook of self-determination research (pp. 183-203). Rochester, NY: The University of Rochester Press.

Reeve, J., Lee, W., \& Won, S. (in press). Interest as emotion and affect. In K.A. Renninger, M. Neiswandt, \& S. Hidi (Eds.) Interest in K-16 mathematics and science learning and related activity. Washington, DC: American Educational Research Association.

Renninger, K. A. (2000). Individual interest and its implications for understanding intrinsic motivation. In C. Sansone \& J. N. Harackiewicz (Eds.), Intrinsic motivation: 
Controversies and new directions (pp. 373-404). New York, NY: Academic Press.

Renninger, K. A., \& Hidi, S. (2011). Revisit the conceptualization, measurement, and generation of interest. Educational Psychologist, 46, 168-184. doi: 10.1080/00461520.2011.587723

Scherer, K. R., Schorr, A., \& Johnstone, T. (Eds.). (2001). Appraisal processes in emotion. Oxford, UK: Oxford University Press.

Schiefele, U. (1991). Interest, learning, and motivation. Educational Psychologist, 26, 299-324. doi: 10.1207/s15326985ep2603\&4_5

Schraw, G., \& Lehman, S. (2001). Situational interest: A review of the literature and directions for future research. Educational Psychology Review, 13, 23-52.

Schutz, P., Pekrun, R. P., \& Phye, G. (Eds.). (2007). Emotion in education. San Diego, CA: Academic Press.

Senko, C., \& Harackiewicz, J. M. (2005). Achievement goals, task performance, and interest: Why perceived goal difficulty matters. Personality and Social Psychology Bulletin, 31, 1739-1753. doi: 10.1177/0146167205281128

Sideridis, G. D. (2007). Goal orientations and classroom goal structures as predictors of classroom behaviors for Greek students with and without learning difficulties: Clarifying the differential role of motivational orientations. Advances in Learning and Behavioral Disabilities, 20, 101-137. doi: 10.1016/S0735-004X(07)20005-9

Silvia, P. (2008). Interest: The curious emotion. Current directions in Psychological Science, 17, 57-60. doi: 10.1111/j.1467-8721.2008.00548.x

Simons, J., Dewitte, S., \& Lens, W. (2004). The role of different types of instrumentality in motivation, study strategies, and performance: Know why you learn, so you'll know what you learn! British Journal of Educational Psychology, 74, 343-360. doi: 10.1348/0007099041552314

Skinner, E., Furrer, C., Marchand, G., \& Kindermann, T. (2008). Engagement and disaffection in the classroom: Part of a larger motivational dynamic? Journal of Educational Psychology, 100, 765-781. doi: 10.1037/a0012840

Tanaka, A., Okuno, T., \& Yamauchi, H. (2013). Longitudinal tests on the influence of achievement goals on effort and intrinsic interest in the workplace. Motivation and Emotion, 37, 457-464. doi: 10.1007/s11031-012-9318-1

Tsai, Y., Kunter, M., Lüdtke, O., Trautwein, U., \& Ryan, R. M. (2008). What makes lessons interesting? The role of situational and individual factors in three school subjects. Journal of Educational Psychology, 100, 460-472. doi:10.1037/0022-0663.100.2.460

Tulis, M., \& Ainley, M. (2011). Interest, enjoyment, and pride after failure experiences? Predictor of students' state-emotions after success and failure during learning in mathematics. Educational Psychology, 31, 779-807. doi: 10.1080/01443410.2011.608524

Turner, S. A., \& Silvia, P. J. (2006). Must things be pleasant? A test of competing appraisal structures. Emotion, 6, 670-674. doi: 10.1037/1528-3542.6.2.670

Vansteenkiste, M., Simons, J., Lens, W., Soenens, B., Matos, L., \& Lacante, M. (2004). Less is sometimes more: Goal content matters. Journal of Educational 
Psychology, 96, 755-764. doi: 10.1037/0022-0663.96.4.755

Van Yperen, N. W. (2006). A novel approach to assessing achievement goals in the context of the $2 \times 2$ framework: Identifying distinct profiles of individuals with different dominant achievement goals. Personality and Social Psychology Bulletin, 32, 1432-1445. doi: 10.1177/0146167206292093

Wigfield, A., \& Anderman, E., \& Eccles, J. (2000, April). Relations among children's ability-related beliefs, achievement values, and achievement goals. Paper presented at the annual meeting of the American Educational Research Association, New Orleans, LA.

Wigfield, A., \& Eccles, J. S. (2000). Expectancy-value theory of motivation. Contemporary Educational Psychology, 25, 68-81. doi: 10.1006/ceps.1999.1015

Wigfield, A., \& Eccles, J. S. (2002). The development of competence beliefs, expectancies for success, and achievement values from childhood through adolescence. In A. Wigfield \& J. S. Eccles (Eds.), Development of achievement motivation (pp. 91-120). San Diego, CA: Academic. 


\section{Footnotes}

${ }^{1}$ Some researchers have proposed that the relationship between task difficulty and interest is curvilinear: interest is decreased when a task is too difficult or too easy, and increased when the difficulty is moderate or optimal (Csikszentmihalyi, 1990; see also Atkinson, 1957). In our study, however, we focused on a university classroom, where tasks are relatively complex and challenging. In such a situation, the task is unlikely to be extremely easy or difficult for students, making it unrealistic to observe such curvilinear relations. Accordingly, the present research focused on linear relationships between difficulty and interest. Our preliminary analysis of the data indeed confirmed the absence of the curvilinear relationship.

${ }^{2}$ To evaluate the potential multicollinearity between the task-specific perception variables, we examined the variance inflation factors (VIF) of within-person variation of expectancy, utility, and difficulty. All of the values were below 2 (1.23 for expectancy, 1.13 for utility, and 1.12 for difficulty), and above the tolerance level of 0.60 ( 0.81 for expectancy, 0.89 for utility, and 0.90 for difficulty), suggesting that multicollinearity would not threaten our findings (Cohen, Cohen, West, \& Aiken, 2003).

${ }^{3}$ We analyzed the potential multicollinearity between the achievement goals by regressing individual averaged interest scores on four achievement goals. The VIF values were 1.60 for mastery-approach goals, 1.77 for mastery-avoidance goals, 1.46 for performance-approach goals, and 1.47 for performance-avoidance goals. The tolerance levels were 0.63 for mastery-approach goals, 0.56 for mastery-avoidance goals, 0.69 for performance-approach goals, and 0.68 for performance-avoidance goals. These results suggest that there are no serious multicollinearity issues with these variables. 
Table 1

Descriptive Statistics of Within-Person Level Variables

\begin{tabular}{|c|c|c|c|c|c|c|c|c|c|c|c|c|c|c|c|c|c|c|c|}
\hline \multirow{4}{*}{ Variable } & \multicolumn{18}{|c|}{ Week } & \multirow{4}{*}{ Cronbach's $\alpha$} \\
\hline & \multirow{3}{*}{$\begin{array}{c}1 \\
\begin{array}{l}\text { Research } \\
\text { methods }\end{array} \\
M(S D) \\
\end{array}$} & \multirow{2}{*}{\multicolumn{4}{|c|}{$\begin{array}{l}2 \\
\text { The brain and the nervous } \\
\text { system }\end{array}$}} & \multirow{2}{*}{\multicolumn{2}{|c|}{$\begin{array}{cc}4 & 5 \\
\text { Sensation and perception }\end{array}$}} & 6 & 5 & 7 & 7 & 8 & 3 & 9 & 10 & 1 & 1 & 12 & \\
\hline & & & & & & & & \multicolumn{4}{|c|}{ Learning } & \multicolumn{3}{|c|}{ Memory } & \multicolumn{3}{|c|}{ Motivation } & \multirow{2}{*}{$\begin{array}{l}\begin{array}{l}\text { Research } \\
\text { methods }\end{array} \\
M(S D)\end{array}$} & \\
\hline & & & $S D)$ & & SD) & $M(S D)$ & $M(S D)$ & & $(S D)$ & $M($ & $S D)$ & $M($ & SD) & $M(S D)$ & $M(S D)$ & $M($ & $S D)$ & & \\
\hline 1. Interest & $3.91(0.61)$ & 3.40 & $(0.83)$ & 3.68 & $(0.77)$ & $3.76(0.74)$ & $4.08(0.71)$ & 3.73 & $(0.78)$ & 3.80 & $(0.67)$ & 3.77 & (0.69) & $3.75(0.77)$ & $3.51(0.75)$ & 3.88 & $(0.65)$ & $3.56(0.76)$ & 0.85 \\
\hline 2. Boredom & $2.16(0.65)$ & 2.60 & $(0.79)$ & 2.58 & $(0.81)$ & $2.53(0.74)$ & $2.18(0.78)$ & 2.45 & $(0.76)$ & 2.42 & $(0.75)$ & 2.40 & $(0.74)$ & $2.43(0.76)$ & $2.58(0.70)$ & 2.39 & $(0.77)$ & $2.52(0.69)$ & 0.86 \\
\hline 3. Expectancy & $3.03(0.59)$ & 2.77 & $(0.72)$ & 2.90 & (0.69) & $2.86(0.64)$ & $3.04(0.60)$ & 2.87 & $(0.67)$ & 2.87 & $(0.55)$ & 2.95 & $(0.60)$ & $2.77(0.68)$ & $2.79(0.63)$ & 2.88 & $(0.69)$ & $2.89(0.60)$ & 0.88 \\
\hline 4. Utility & $3.59(0.67)$ & 3.28 & $(0.68)$ & 3.35 & $(0.73)$ & $3.35(0.74)$ & $3.54(0.71)$ & 3.48 & $(0.73)$ & 3.42 & $(0.63)$ & 3.39 & $(0.71)$ & $3.45(0.77)$ & $3.33(0.71)$ & 3.51 & $(0.79)$ & $3.35(0.66)$ & 0.74 \\
\hline 5. Difficulty & $2.66(0.81)$ & 3.33 & $(0.82)$ & 3.22 & $(0.80)$ & $2.99(0.76)$ & $2.80(0.76)$ & 3.12 & $(0.78)$ & 3.11 & $(0.67)$ & 2.98 & (0.69) & $3.01 \quad(0.74)$ & $3.15(0.72)$ & 2.92 & $(0.75)$ & $2.84(0.70)$ & 0.81 \\
\hline$n$ & 158 & 13 & 32 & & 29 & 134 & 127 & & 27 & 11 & 5 & 13 & 1 & 130 & 132 & 12 & 21 & 133 & \\
\hline
\end{tabular}

Note. The topic of each week is noted under the week number 
Running Head: INTEREST AND BOREDOM

Table 2

Within-Person Level Correlations of Interest, Boredom, and Task-Specific Perceptions

\begin{tabular}{llllll}
\hline \multicolumn{1}{c}{ Variable } & \multicolumn{1}{c}{1} & \multicolumn{1}{c}{2} & 3 & 4 & 5 \\
\hline 1. Interest & - & & & & \\
2. Boredom & $-.45^{*}$ & - & & & \\
3. Expectancy & $.28^{*}$ & $-.21^{*}$ & - & & \\
4. Utility & $.43^{*}$ & $-.27^{*}$ & $.34^{*}$ & - & \\
5. Difficulty & $-.19^{*}$ & $.28^{*}$ & $-.32^{*}$ & $-.14^{*}$ & - \\
\hline Note. ${ }^{*} p<.05$ & & & & &
\end{tabular}


Table 3

Descriptive Statistics and Zero-Order Correlations Between Achievement Goals $(N=158)$

\begin{tabular}{lccccccc}
\hline Variable & $M$ & $S D$ & Cronbach's $\alpha$ & 1 & 2 & 3 & 4 \\
\hline 1. Mastery-approach goals & 3.64 & 0.59 & 0.62 & - & & & \\
2. Mastery-avoidance goals & 3.61 & 0.64 & 0.60 & $.59^{*}$ & - & & \\
3. Performance-approach goals & 3.50 & 0.86 & 0.89 & $.14^{*}$ & $.32^{*}$ & - & \\
4. Performance-avoidance goals & 3.60 & 0.85 & 0.85 & -.01 & .28 & $.53^{*}$ & - \\
\hline
\end{tabular}

Note. ${ }^{*} p<.05$ 
Table 4

Within-Person Relationship Between Task-Specific Perceptions and Interest and Boredom

\begin{tabular}{llc}
\hline & \multicolumn{1}{c}{ Interest } & Boredom \\
\hline Fixed effects & \multicolumn{2}{c}{ Coefficient } \\
\hline Intercept $\left(\gamma_{00}\right)$ & $3.74^{* * *}$ & $2.44^{* * *}$ \\
Expectancy $\left(\gamma_{10}\right)$ & $0.17^{* * *}$ & $-0.08^{*}$ \\
Utility $\left(\gamma_{20}\right)$ & $0.42^{* * *}$ & $-0.29^{* * *}$ \\
Difficulty $\left(\gamma_{30}\right)$ & $-0.12^{* * *}$ & $0.23^{* * *}$ \\
& \multicolumn{2}{c}{ Variance } \\
\hline Random effects & $0.19^{* * *}$ & $0.20^{* * *}$ \\
\hline Intercept $\left(u_{0 \mathrm{j}}\right)$ & 0.03 & $0.07^{* * *}$ \\
Expectancy $\left(u_{1 \mathrm{j}}\right)$ & 0.05 & $0.05^{* *}$ \\
Utility $\left(u_{2 \mathrm{j}}\right)$ & $0.04^{* *}$ & 0.03 \\
Difficulty $\left(u_{3 \mathrm{j}}\right)$ & $0<.001$. \\
\hline
\end{tabular}

Note. ${ }^{*} p<.05,{ }^{* *} p<.01,{ }^{* * *} p<.001$. 
Table 5

Interest and Boredom as a Function of Task-Specific Perceptions and Achievement Goals

\begin{tabular}{lcc}
\hline Variable & Interest & Boredom \\
\hline Fixed effects & \multicolumn{2}{c}{ Coefficient } \\
\hline Intercept $\left(\gamma_{00}\right)$ & $3.74^{* * *}$ & $2.44^{* * *}$
\end{tabular}

Between-person level predictors of intercept

Mastery-approach goals $\left(\gamma_{01}\right)$

$0.22 * * \quad-0.24 * *$

Mastery-avoidance goals $\left(\gamma_{02}\right)$

$0.14 * \quad-0.04$

Performance-approach goals $\left(\gamma_{03}\right)$

$0.05 \quad 0.03$

Performance-avoidance goals $\left(\gamma_{04}\right)$

$0.01 \quad 0.04$

Between-person level predictors of Expectancy slope

Intercept $\left(\gamma_{10}\right)$

Mastery-avoidance goals $\left(\gamma_{12}\right)$

Performance-avoidance goals $\left(\gamma_{14}\right)$
$0.16 * * *$

- $-0.12 *$

$-0.08^{*}$

Between-person level predictors of Utility slope

Intercept $\left(\gamma_{20}\right)$

Mastery-approach goals $\left(\gamma_{21}\right)$

$\begin{array}{cl}0.41 * * * & -0.29 * * * \\ - & 0.13 *\end{array}$

Between-person level predictors of Difficulty slope
Intercept $\left(\gamma_{30}\right)$
$-0.12 * * *$
$0.23 * * *$
Mastery-approach goals $\left(\gamma_{31}\right)$
$0.13 * *$

\begin{tabular}{llc}
\hline Random effects & \multicolumn{2}{c}{ Variance } \\
\hline Intercept $\left(u_{0 \mathrm{j}}\right)$ & $0.15^{* * *}$ & $0.18^{* * *}$ \\
Expectancy $\left(u_{1 \mathrm{j}}\right)$ & 0.03 & $0.06^{* * *}$ \\
Utility $\left(u_{2 \mathrm{j}}\right)$ & 0.06 & $0.04^{* *}$ \\
Difficulty $\left(u_{3 \mathrm{j}}\right)$ & $0.04^{* *}$ & 0.03 \\
\hline
\end{tabular}




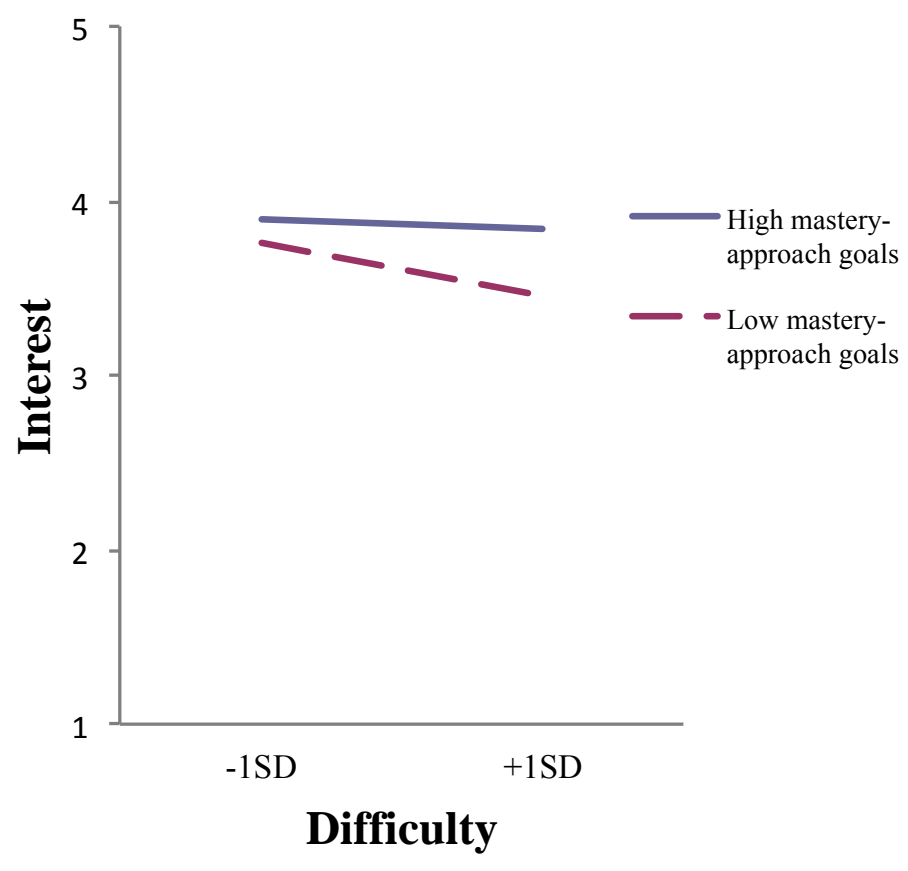

Figure 1. Predicted values for interest as a function of mastery-approach goals at high and low levels of difficulty. 
(A)

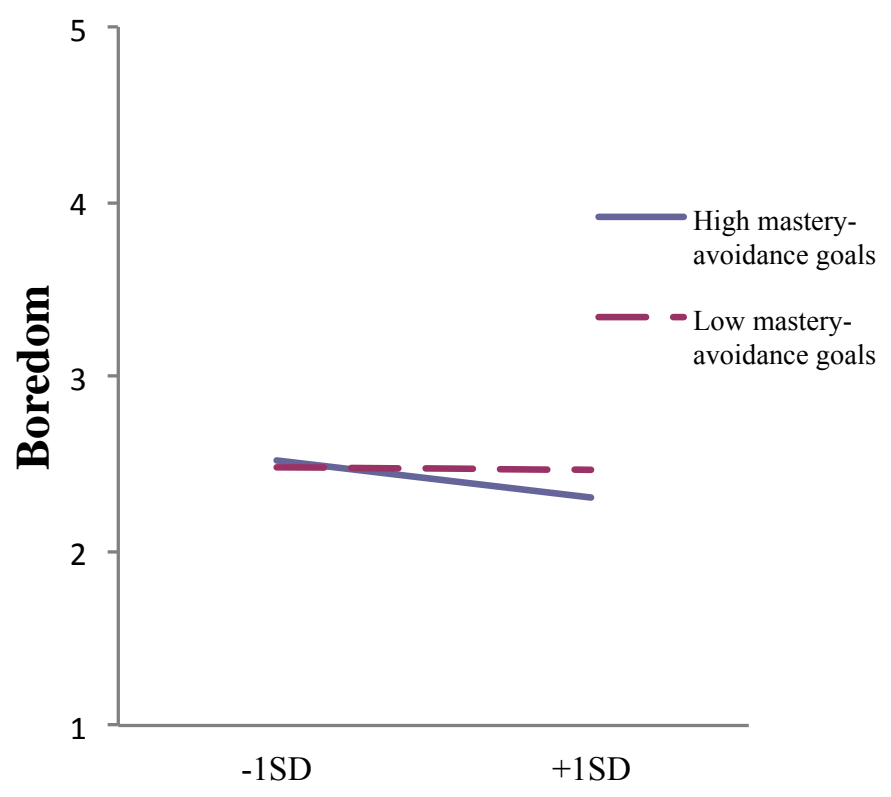

(B)

\section{Expectancy}

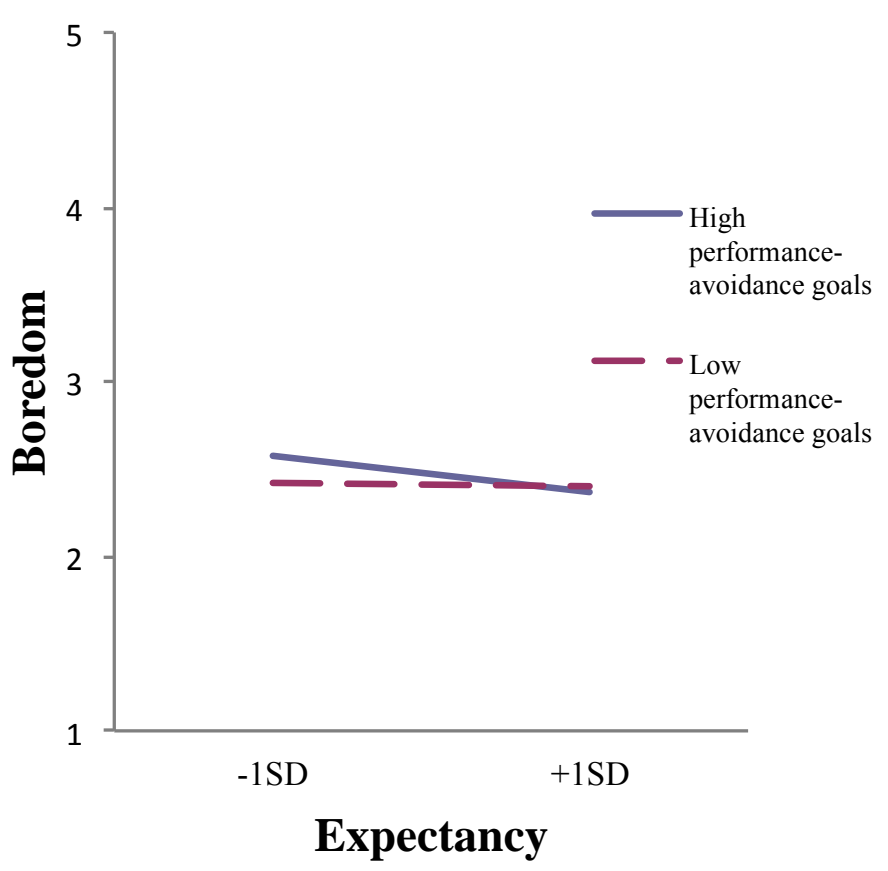

Figure 2. Predicted values for boredom as a function of (A) mastery-avoidance goals and (B) performance-avoidance goals at high and low levels of expectancy. 


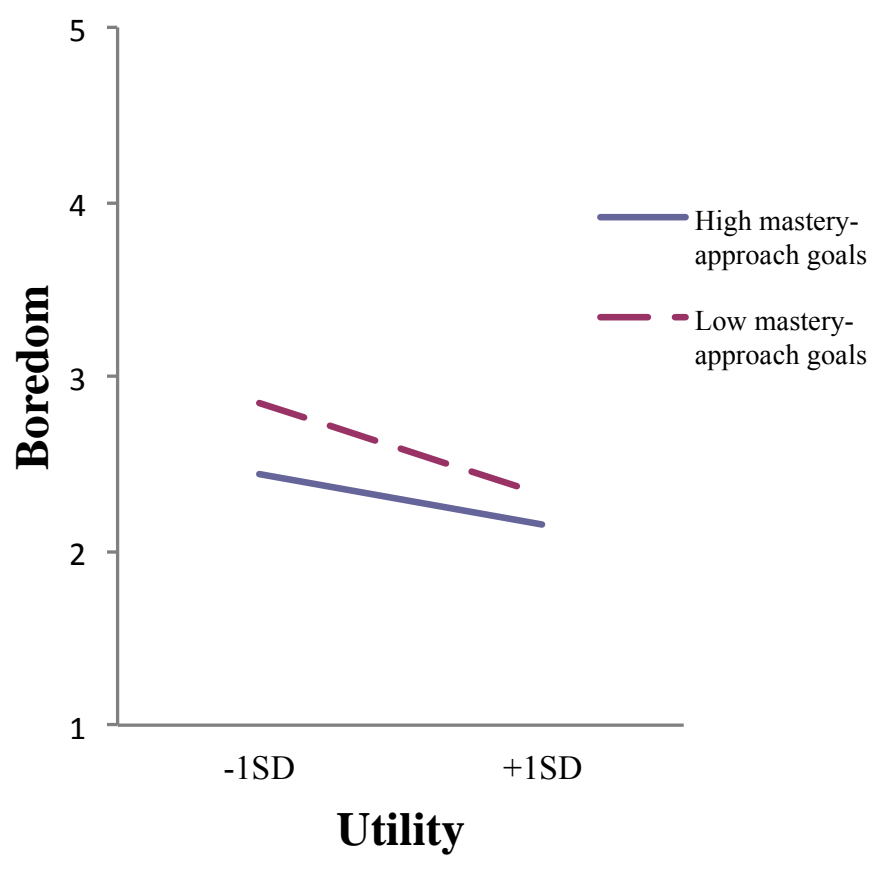

Figure 3. Predicted values for boredom as a function of mastery-approach goals at high and low levels of utility. 